\title{
A STUDY ON THE RELATIONSHIP
}

\section{BETWEEN COMPETITIVE ADVANTAGE}

\section{AND SUPPLY CHAIN ENABLERS IN}

\section{MANUFACTURING SECTOR IN}

\author{
SRI LANKA
}

by

WICKRAMA ARACHCHILAGE DEEPTHI NILMINI WICKRAMAARACHCHI

M.Sc. in Management 


\section{A STUDY ON THE RELATIONSHIP}

\section{BETWEEN COMPETITIVE ADVANTAGE}

AND SUPPLY CHAIN ENABLERS IN MANUFACTURING SECTOR IN

\section{SRI LANKA}

by

\section{WICKRAMA ARACHCHILAGE DEEPTHI NILMINI WICKRAMAARACHCHI}

\section{GS/M.Sc./MGT/3456/08}

Thesis submitted to the University of Sri Jayewardenepura for the award of the Degree of Master of Science in Management (Finance) on 
The work described in this thesis was carried out by me under the supervision of Prof. K. D. Gunawardana and a report on this has not been submitted in whole or in part to any university or any other institution for another Degree/Diploma.

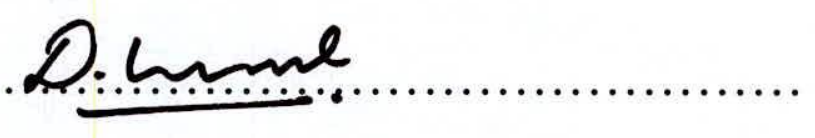

\section{W A D N WICKRAMAARACHCHI}


I certify that the above statement made by the candidate is true and that this thesis is suitable for submission to the University for the purpose of evaluation.

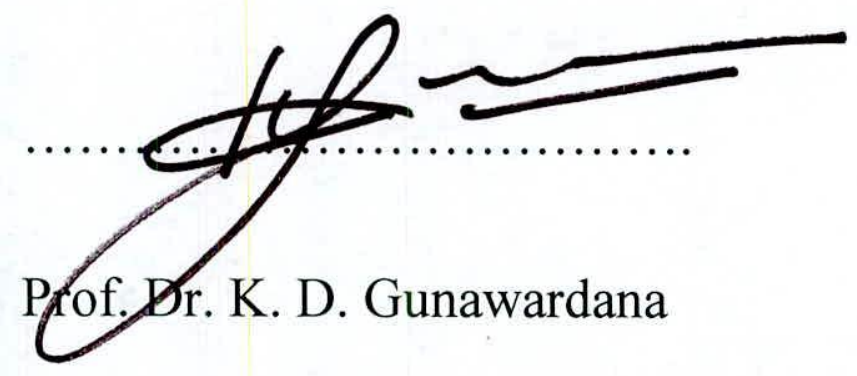

Supervisor

Date

\section{Coordinator}

$\mathrm{PhD}$ in Management Program

Faculty of Management Studies \& Commerce

University of Sn Jayewardenepura

Nugegoda. 


\section{TABLE OF CONTENTS}

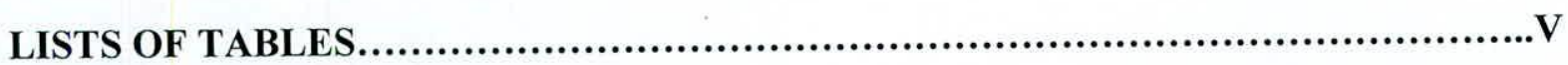

LISTS OF FIGURES.............................................................

ACKNOWLEDGEMENT..........................................................II

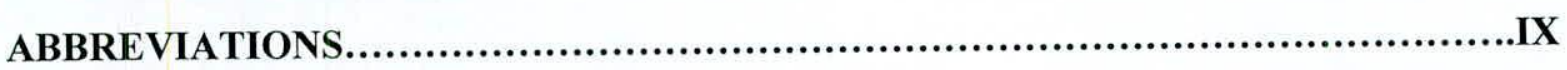

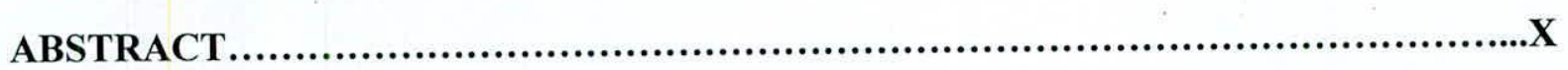

CHAPTER 1 - INTRODUCTION ..................................................

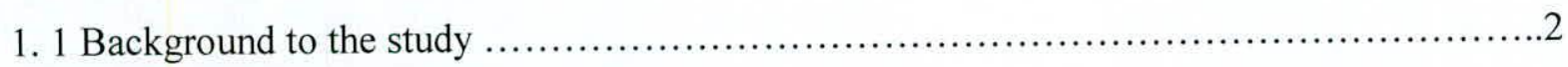

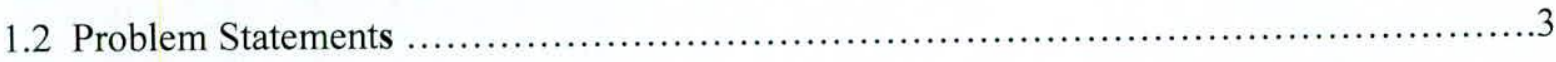

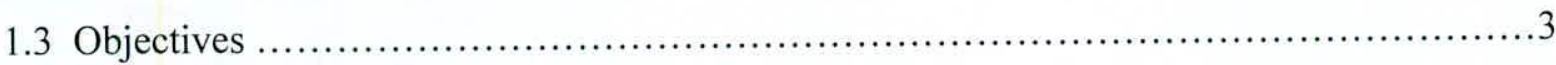

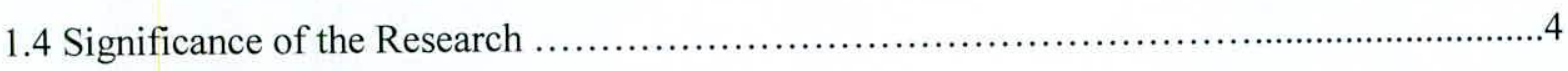

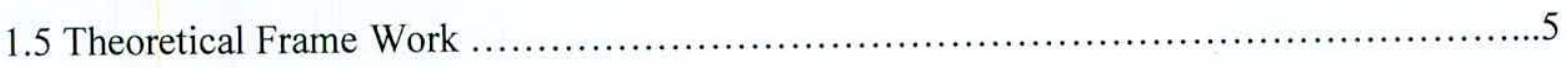

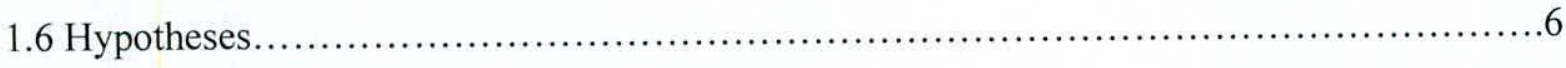

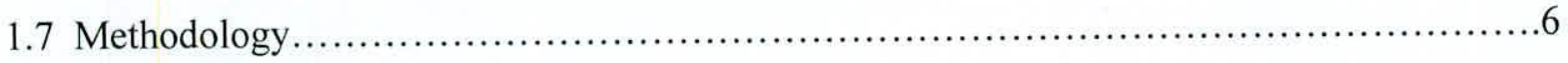

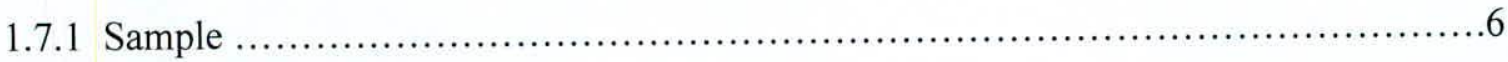

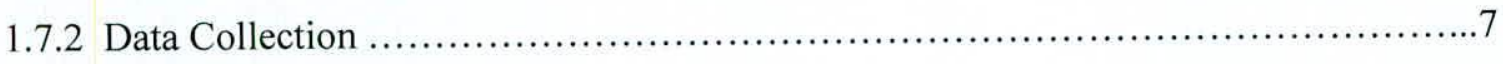

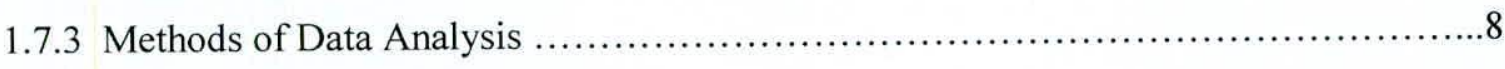

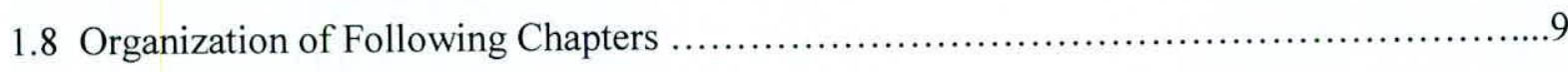

CHAPTER 2 - LITERATURE REVIEW ...........................................10

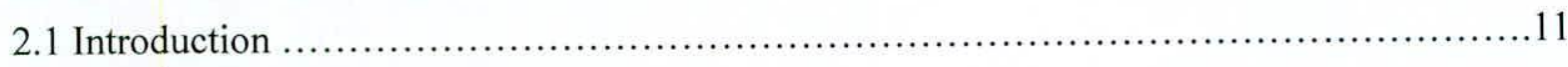

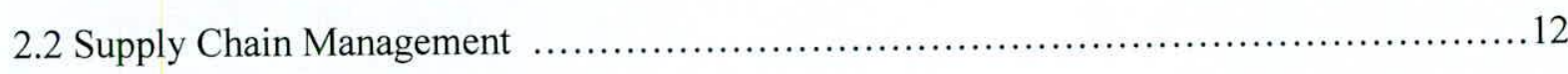




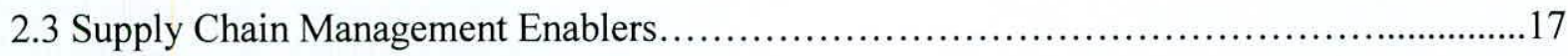

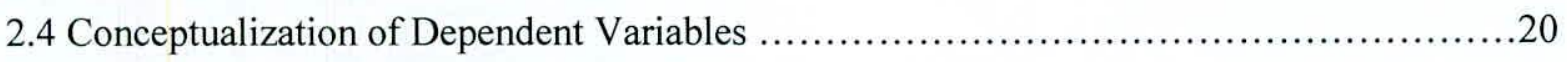

2.4.1 Organizational Performance ...........................................20

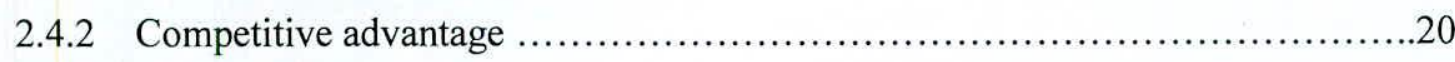

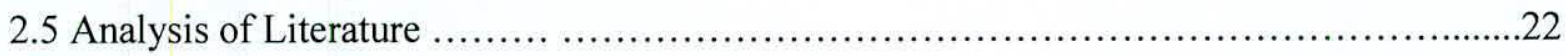

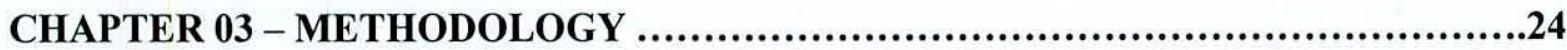

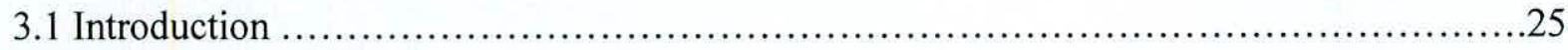

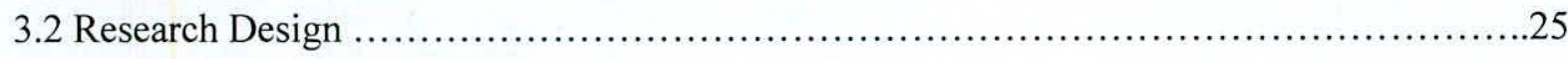

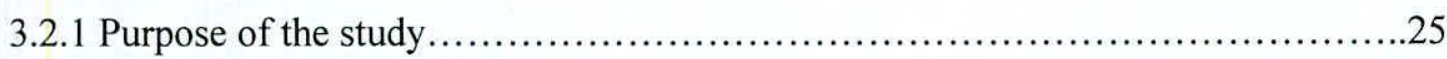

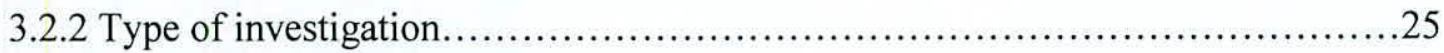

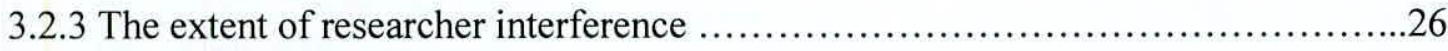

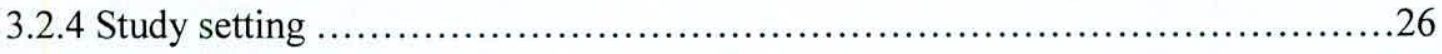

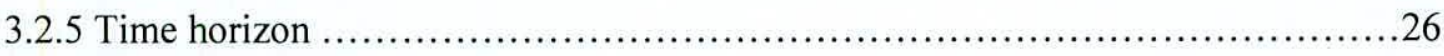

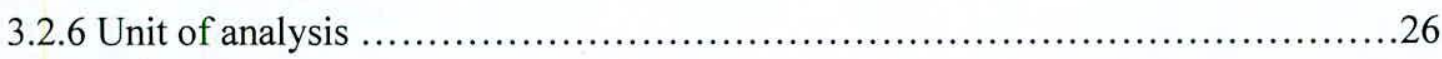

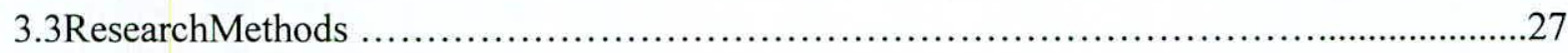

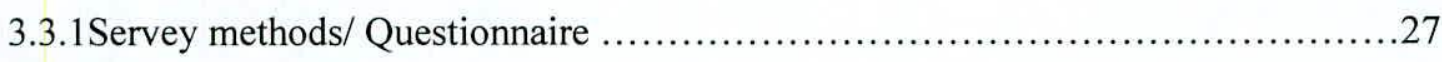

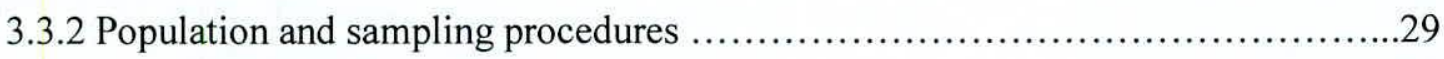

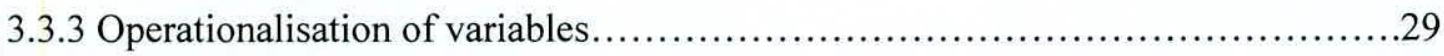

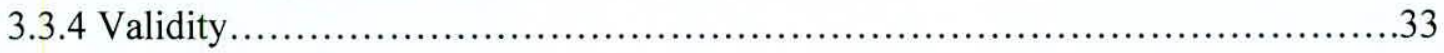

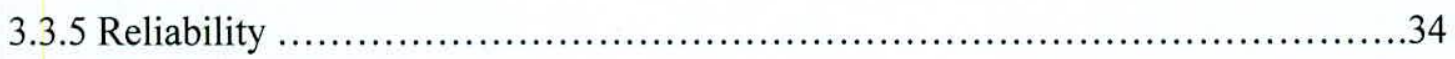

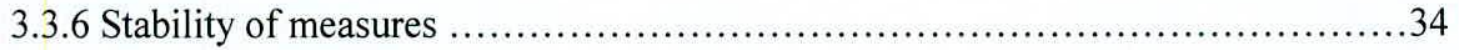




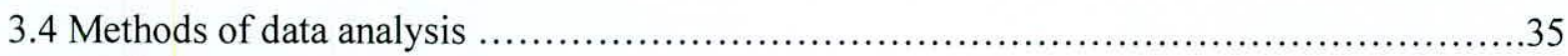

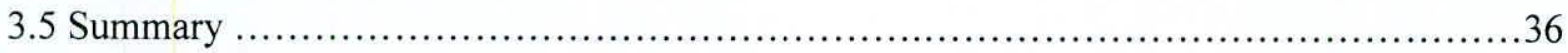

CHAPTER 04 - RESULTS AND DISCUSSION ...........................................39

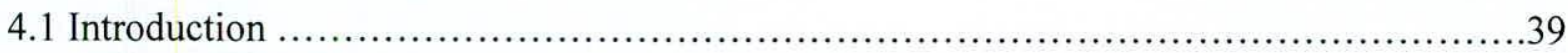

4.2 Analysis of Reliability and Validity of the Instrument ..................................

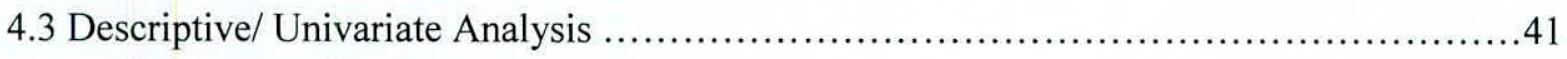

4.3.1 Analysis of Sample Profile..................................................41

4.3.2 Company Demographic Information ........................................ 45

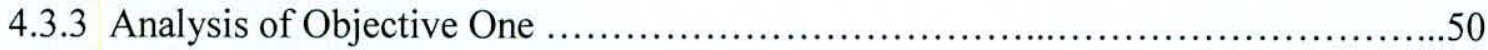

4.4 The use of Supply Chain Management practices.......................................

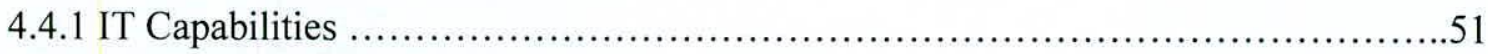

4.4.2 The Degree of Supply Chain Integration ....................................54

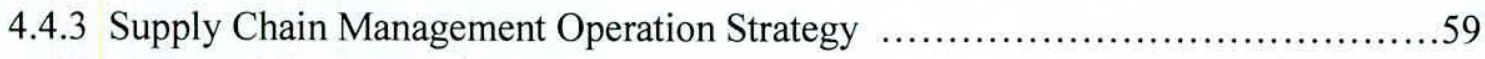

4.5 Business Performance of selected organizations ...................................61

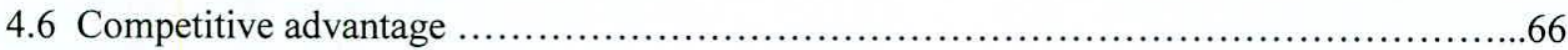

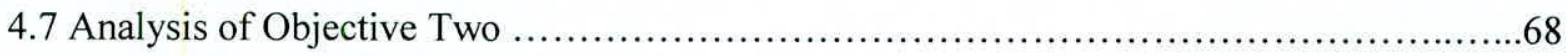

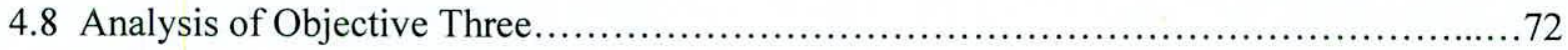




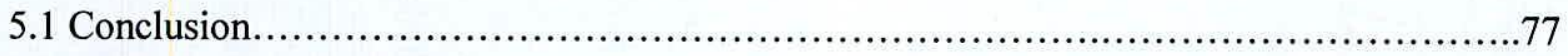

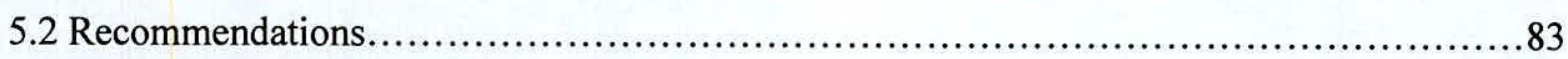

5.3 Limitations of the Research............................................................

5.4 Further research directions.......................................................... 84

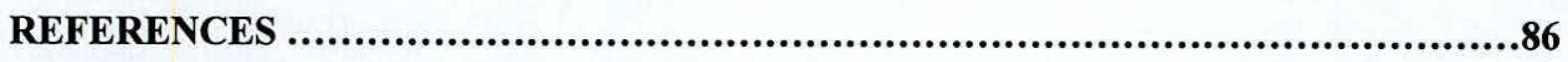

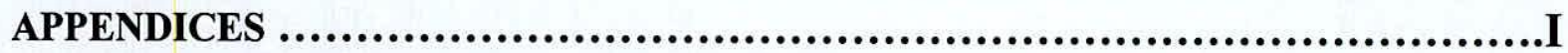

Appendix - 1 The Questionnaire Used for the Study .................................

Appendix - 2 Output of the Data Analysis .....................................viii 


\section{LISTS OF TABLES}

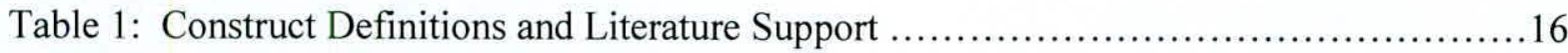

Table 2: List of Sub-Constructs for SCM Practices .........................................

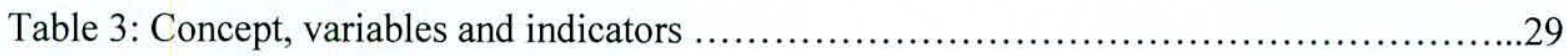

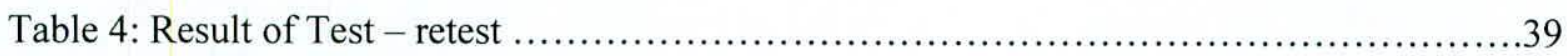

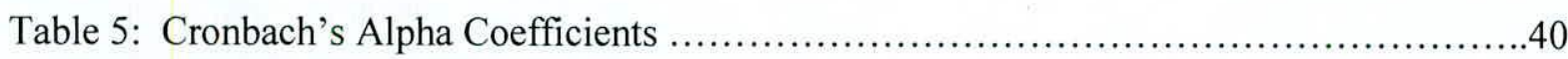

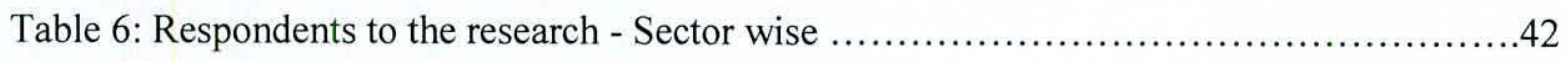

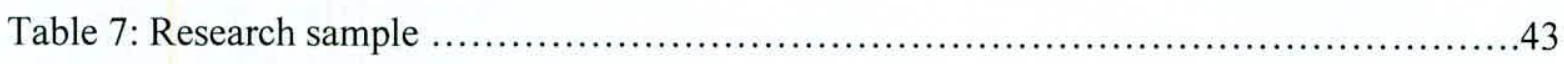

Table 8: Number of employees in selected companies ............................... 45

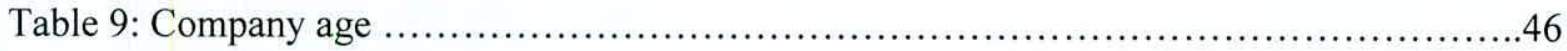

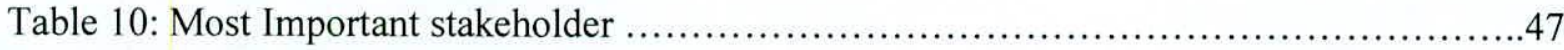

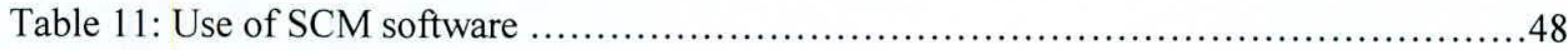

Table 12: Summary of descriptive statistics of constructs- Independent variables ..............50

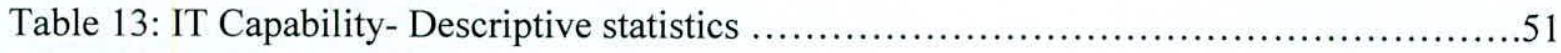

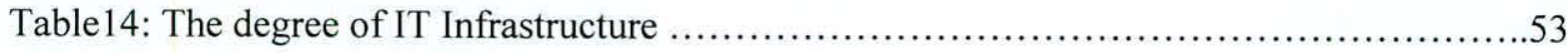

Table 15: The level of Internal Integration -Descriptive Statistics .........................55

Table 16: Level of External Integration -Descriptive Statistic .............................57

Table 17: Factors consider in selecting key suppliers...................................59

Table18: The level of Customer Relationship -Descriptive Statistics ........................60 
Table 19: Financial Performance- Descriptive Statistics 61

Table 20: Logistics Cost performance -Descriptive Statistics .64

Table 21 : Logistics time performance - Descriptive Statistic .65

Table 22: Competitive advantage -Descriptive Statistics .67

Table 23: Regression Model Summary .68

Table 24: ANOVA Results .69

Table 25: Regression Coefficients .69

Table 26: ANOVA Results . .70

Table 26: ANOVA Results .70

Table 28: ANOVA Results .71

Table 29: Correlation Matrix .71

Table 30: Regression Model Summary .72

Table 31: ANOVA Results .73

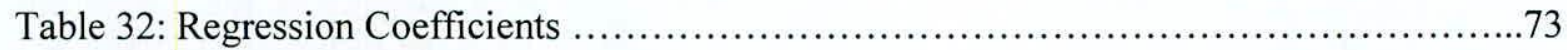

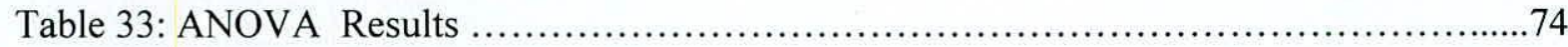

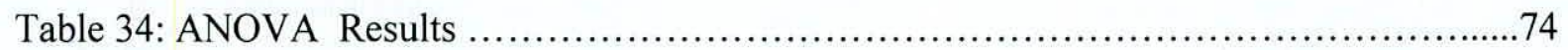

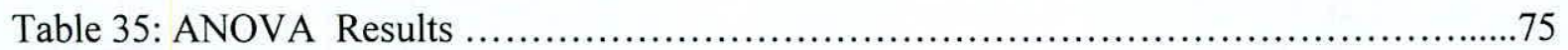




\section{LISTS OF FIGURES}

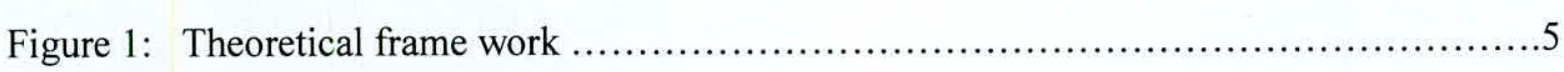

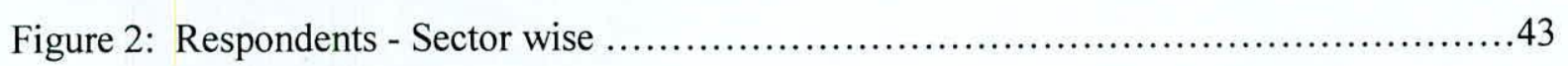

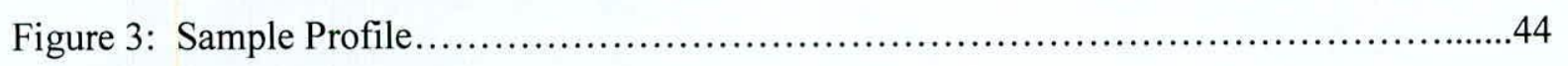

Figure 4: Number of employees in selected companies ................................ 45

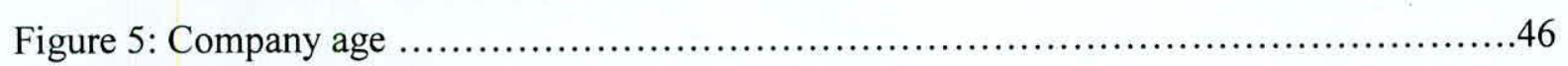

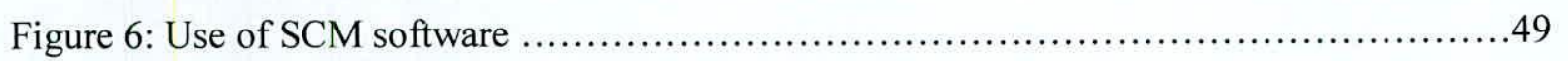

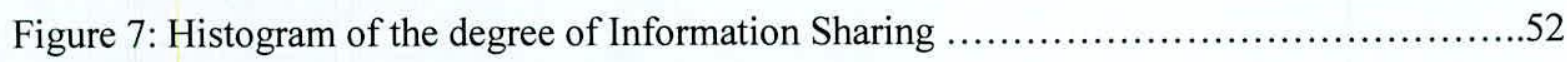

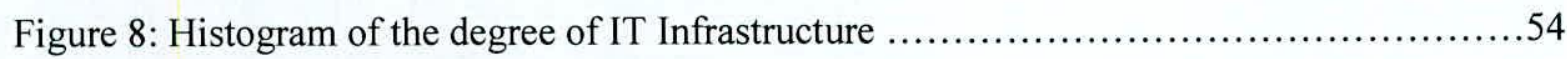

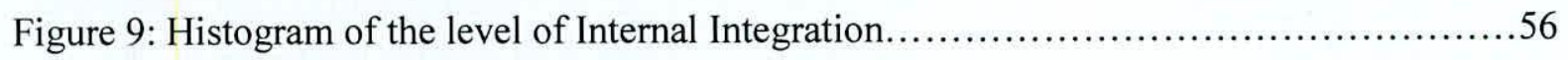

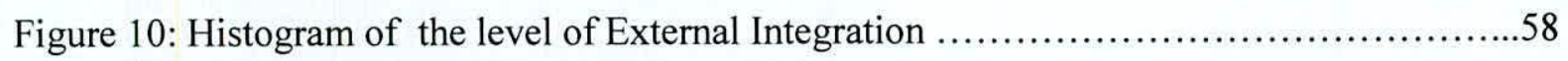

Figure 11: Histogram of the Financial Performance after introducing SCM practices..........62

Figure 12: Histogram of the Logistics Cost...........................................64

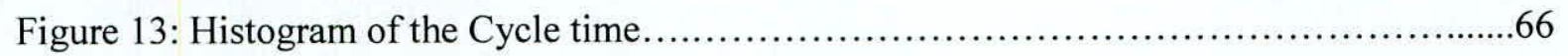




\section{ACKNOWLEDGEMENT}

First and foremost, I would like to convey my gratitude to my animated and inspirational supervisor, Prof. K. D. Gunawardana, Professor of Accounting, Department of Accountancy, University of Sri Jayawardenapura for all the guidance, assistance and continuous encouragement provided to me. It was his gentle guidance with patience, motivation and immense knowledge encouraged me to accomplish the successful completion of this research. The immense support given by him is highly valued and appreciated.

My sincere thanks to Dr. P. D. Nimal, former coordinator of M.Sc. (Management) programme, for all his contribution and valuable advices. I would also like to extend my gratitude to all lectures who conducted lectures for the course work of M.Sc. (Management) programme 2007/ 2008.

I express my exclusive gratitude to all the respondents who completed the questionnaires and returned them on time for enabling me to analyze the data without delay.

My big thanks are forwarded to my staff mates of the Department of Transport and Logistics Management, Faculty of Engineering, University of Moratuwa including Engineer Ranil Sugathadasa, Prof. Amal S.Kumarage and friends who genuinely encouraged, supported and assisted me in many ways to make this endeavor a success. 


\section{ABBREVIATIONS}

SCM Supply Chain Management

CSCMP Council of Supply Chain Management Professionals

CLM Council of Logistics Management

GSCF Global Supply Chain Forum

ROI Return on Investment

IT Information Technology

ANOVA Analysis of Variance

SPSS Statistical Package for Social Sciences 


\title{
A STUDY ON THE RELATIONSHIP BETWEEN COMPETITIVE ADVANTAGE AND SUPPLY CHAIN ENABLERS IN MANUFACTURING SECTOR IN SRI LANKA
}

\section{WADN Wickramaarachchi}

\begin{abstract}
During last few decades, the effective supply chain management (SCM) has become a potentially valuable way of securing competitive advantage and improving organizational performance. In present day organizational context the competition is no longer between organizations, but among supply chains. This research conceptualizes and develops three dimensions of SCM practice (Information Technology Capability, Supply Chain Integration and Supply Chain Management Operation Strategy) and tests the relationships between SCM practices and organizational performance. Data for the study were collected from 35 Sri Lankan manufacturing organizations and the relationships proposed in the framework were tested using Statistical Package for Social Sciences (SPSS 14). The results indicate that the higher levels of SCM practice can improve the organizational performance and can lead the organization to achieve greater benefits of competitive advantage. IT capability is shown as the most critical enabler and it is the fundamental driver of supply chain management. Also, IT capability and supply chain integration can have a direct, positive impact on organizational performance. Hence, the SCM practices can be recognized as the most critical strategic aspects of today's organizations .Organizations can achieve short-term as well as long-term strategic objectives by improving SCM practices at their organizations.
\end{abstract}

Keywords: Supply chain management; Organizational performance; Supply Chain Integration 


\section{CHAPTER 1}

\section{INTRODUCTION}

\section{CHAPTER OUTLINE}

1. 1 Background to the Study

1.2 Problem Statements

1.3 Objectives

1.4 Significance of the Research

1.5 Theoretical Frame Works

1.6 Hypotheses

1.7 Methodology

1.7.1 Sample

1.7.2 Data Collection

1.7.3 Methods of Data Analysis

1.8 Organization of Following Chapters 